\title{
LA SONATA DE OTONO: UN HITO EN EL DESARROLLO HACIA EL NIHILISMO ACTIVO
}

Una lectura de la Sonata de otoño (1902) de Ramón del Valle-Inclán revela un tratamiento curioso de la relación hombre-mujer. Se basa en los dos tipos de nihilismo de Friedrich Nietzsche (18441900), el activo y el pasivo. Durante la época en que Valle-Inclán escribió su Sonata de otoño la filosofía de Nietzsche ya estaba en boga en Europa. En el mismo año de 1902, Martínez Ruiz publica su novela La voluntad. Nietzsche era tan conocido en España que Azorín ya puede meditar abiertamente "la angustia que sentía Nietzsche"1. Dos años después de la publicación de las dos novelas, La voluntad y la Sonata de otoño, Pío Baroja comenta "el éxito de Nietzsche"': "por todas partes, en revistas, libros y periódicos, sobre todo en los extranjeros, no se hace más que citar el nombre del célebre filósofo prusiano'’2. Juan Ramón Jiménez percibe la influencia de Nietzsche en España al hablar de la generación del $98^{3}$, grupo contemporáneo de los modernistas. A causa de este ambiente, no debe extrañar que tanto Gonzalo Sobejano como Antonio Vilanova sugieran una posible influencia de Nietzsche en la ideología de Valle-Inclán . 1984.

' José Martínez Ruiz, La voluntad, ed. E. Inman Fox, Castalia, Madrid,

2 Pío Baroja, "El éxito de Nietzsche", en El tablado de Arlequín, en Obras completas, Biblioteca Nueva, Madrid, 1948, t. 5, p. 18.

3 Citado en Allen W. Phillips, Temas del modernismo hispánico y otros ensayos, Credos, Madrid, 1974, p. 163.

${ }^{4}$ Gonzalo Sobejano, Nietzsche en España, Gredos, Madrid, 1967, p. 216. En adelante, se indicarán las referencias de este libro abreviadas en GS con el número de la página entre paréntesis; ANTONio Vilanova, "El tradicionalismo anticastizo, universal y cosmopolita, de las Sonatas de Valle-Inclán", en Homenaje a Antonio Sánchez Barbudo. Ensayos de literatura española moderna, eds. Benito Brancaforte, Edward R. Mulvihill y Roberto G. Sánchez, University of Wisconsin, Madison, 1981, p. 366. 
En un texto tan básico como el Oxford companion to Spanish literature se notan los vínculos entre el nihilismo y el comportamiento del protagonista de la Sonata de otoño $0^{5}$. Aunque se ha documentado la influencia de Nietzsche en Luces de Bohemia ${ }^{6}$, curiosamente no se ha llevado a cabo un estudio detallado que relacione concretamente la Sonata de otoño con los elementos esenciales del nihilismo nietzscheano. Así pues, en este trabajo se van a cotejar las características de los dos personajes principales de la Sonata de oto$\tilde{n} o$ con los dos tipos de nihilismo descritos por Nietzsche en su Voluntad de poderio (1901). Se verá que el nihilismo pasivo explica el comportamiento de la protagonista femenina, Concha. Por otra parte, el nihilismo activo se convierte en la fuerza vital del hombre, el marqués. De esta suerte, aunque Valle-Inclán, en el mismo año de 1902, llegara a reprobar a "los literatos de ideas"' (por no saber cómo "construir una oración") ${ }^{7}$, usó el modernismo para disfrazar sus ideas, acercándose a la filosofía de Nietzsche.

El nihilismo provee la base filosófica para definir la naturaleza tanto del hombre como de la mujer en la novela. El hombre y la mujer se conciben en la novela como polos opuestos, que se atraen mutuamente. Esta doble faceta de la unidad humana, tan destacada en la pareja protagonista, es tan aparente que incluso se refleja continuamente en el medio ambiente de esta novela. En la capilla del palacio de Brandeso se encuentran dos estatuas que representan fielmente el tratamiento de los sexos en la Sonata. Por una parte, los hombres se caracterizan como los fuertes: "A la derecha del altar estaba enterrado el Capitán Alonso Bendaña con otros caballeros de su linaje: el sepulcro tenía la estatua orante de un guerrero"'. Por otra parte, la mujer concretiza el lado extremo: "A la izquierda estaba enterrada Doña Beatriz de Montenegro, con otras damas de distinto abolengo: el sepulcro tenía la estatua orante de una religiosa en hábito blanco como las Comendadoras de Santiago"' (p. 74). El narrador termina atribuyendo

${ }^{5}$ Phillip WARD, Oxford companion to Spanish literature, Clarendon PressOxford University Press, Oxford, 1978, p. 553.

${ }^{6}$ Alan E. Smith, "Luces de Bohemia y la figura de Cristo: Valle-Inclán, Nietzsche y los románticos alemanes", HR, 57 (1989), 57-71. En adelante, todas las referencias a este artículo irán abreviadas en $A S$.

7 Ramón del Valle-InClán, "A ras de tierra", El imparcial, Madrid, 9 de junio de 1902. El artículo fue reproducido por Eliane LaVAud, "ValleInclán y la crítica literaria (1894-1903)', $H R, 47$ (1979), 159-183, esp. 175-177.

${ }^{8}$ Ramón del Valle-Inclán, Sonata de otoño, Espasa-Calpe, Madrid, 1969, p. 74. En adelante, todas las referencias a este libro aparecerán en el texto con el número de la página entre paréntesis. 
ciertos rasgos privativos a cada sexo: "¡era tradicional que en el linaje de Brandeso los hombres fuesen crueles y las mujeres piadosas!' (id.). Este alejamiento entre el varón y la mujer en la Sonata no puede entenderse sin comparar ambos sexos con los elementos de los dos tipos de nihilismo nietzscheano.

Para entender cómo funciona el nihilismo en la elaboración de estos dos tipos humanos, se resumirán primero los puntos esenciales del nihilismo pasivo y cómo se relacionan con el comportamiento de la mujer, Concha. A continuación, se examinará el nihilismo activo y cómo este último determina el comportamiento del hombre, el marqués.

En Nietzsche, el nihilismo pasivo se asocia con la moral. Para el pensador germánico, este concepto cristiano pudo capturar el espíritu humano occidental porque "concedía al hombre un valor absoluto, por oposición a su pequeñez y a su contingencia en la corriente del devenir y el desaparecer" ". El ente humano que acepta este "valor absoluto" se concibe como nihilista pasivo porque "la moral es la renuncia a la Voluntad de existir"' (VP, p. 35) ${ }^{10}$. Privado de la Voluntad, el nihilista pasivo no puede alcanzar nada excepto la beatitud ( $V P$, p. $37 ; G W$, t. 18, p. 16). Ferrater Mora explica que, desde la perspectiva del beato, la Voluntad, por ser apartada del "valor absoluto" de la moral cristiana, es la "raíz de todo mal en general"'11.

${ }^{9}$ Para facilitar la lectura de este estudio me limito a poner las citas originales en notas al final del trabajo. Por la misma razón, las traducciones de estas citas se ubican dentro del texto mismo. Federico Nietzsche, La voluntad de poderio, EDAF, Madrid, 1981, p. 33: (VP): "sie verlieh dem Menschen einen absoluten Werth, im Gegensatz zu seiner Kleinheit und Zufälligkeit im Strom des Werdens und Vergehens", Friedrich Nietzsche, Gesammelte Werke, Bs. 18 y 19. Der Wille zur Macht: Versuch einer Umwerthung aller Werthe. Cuatro libros, los 1 y 2 corresponden al t. 18, los 3 y 4 al 19. Musarion Verlag, München, 1926 , t. 18 , p. 11. En adelante, las referencias a esta obra irán abreviadas en $G W$ con el número del volumen y el número de la página entre paréntesis. Debe advertirse que Nietzsche dejó este libro en forma esquemática no terminada. Por esto algunas de las citas parecen ser gramaticalmente incorrectas.

10 "Moral ist die Abkehr vom Willen zum Dasein..." (GW, t. 18, p. 14). Se respetará fielmente la traducción de Castrillo Mirat con una excepción: de acuerdo con el Diccionario de Ferrater Mora, se sustituirá la minúscula v por $\mathrm{V}$ en la palabra Voluntad ya que el concepto en Nietzsche toma más importancia que el de Dios.

11 José Ferrater Mora, Diccionario de filosofía de bolsillo, Alianza, Madrid, 1983 , t. 2, p. 557. En adelante, las referencias a esta obra irán abreviadas en $F M$ con el número del tomo y de la página entre paréntesis. 
Sin la Voluntad, y sujeto a todos los dogmas cristianos de la moral, el ser humano sufre del miedo a las penas eternas y de un sentimiento de culpa. Para Nietzsche, la religión es "una especie de sentimiento de miedo y temor ante sí mismo" (VP, p. 102)12. Este miedo y complejo de culpa del nihilismo pasivo conduce al "nihilismo [concebido] como decadencia y retroceso del poder del espíritu"' (VP, p. 41) 13. El espíritu retrocede frente a "un más allá de la vida, en el que la gran máquina de castigar se representa ya en acción" (VP, p. 107) ${ }^{14}$. Vaciado de fuerza vital el cristiano no tiene más remedio que guardar "un "alma hermosa" en un aborto de cadáver" (VP, p. 148) $)^{15}$. Despreocupándose de la salud física a favor del terror divino, el individuo se convierte en un ser "pálido" y "enfermizo" (id. $)^{16}$. El nihilismo pasivo "se conforma con un cristianismo narcotizante, debido a que ya no tiene fuerzas para buscar la lucha, ni para aventurarse, ni para desear quedarse solo"' (VP, p. 155) ${ }^{17}$. Ya que hay una negación completa de la Voluntad, el nihilista pasivo tiene que renunciar al orgullo, la responsabilidad, la exuberancia, la animalidad, los instintos guerreros, la apoteosis de la pasión, de la voluptuosidad, de la ira y de la aventura (VP, p. $145 ; G W$, t. 18, p. 162).

Curiosamente Nietzsche no solamente divide la humanidad en nihilistas pasivos y activos, sino que considera a las mujeres partidarias del nihilismo pasivo mientras que concibe a los hombres como exponentes del activo. Es así que no pudo concebir la

12 "Eine Art Furcht- und Schreckgefühl vor sich selbst..." (GW, t. 18, p. 105).

13 "Nihilismus als Niedergang und Rückgang der Macht des Geistes" (GW, t. 18, p. 22).

14 "ein Jenseits des Lebens, in dem die grosse Straf-Maschine, erst wirksam gedacht wird" (GW, t. 18, p. 111).

15 "eine "schöne Seele" in einer Missgeburt von Cadaver herumtragen..." (GW, t. 18, p. 165). La palabra "herumtragen" no se presenta en la traducción castellana. Sin embargo, ésta representa correctamente el significado y sentimiento generales del texto original.

16 "bleiches", "krankhaftes" (GW, t. 18, p. 165). Algunos diccionarios (como el Cassell's German dictionary) traducen "krankhaft" como "mórbido". Sin embargo, de acuerdo con el contexto, la traducción española que se maneja aquí, "enfermizo" y la traducción inglesa de Walter Kaufmann, "sickly", (The will to power, Random House, New York, 1967, p. 226), en este estudio se emplea la acepción de "enfermizo".

17 " $m a n$ begnügt sich mit einem opiatischen Christenthum, weil man weder zum Suchen, Kämpfen, Wagen Alleinstehen-wollen die Kraft hat"' ( $G W$, t. 18, p. 176). 
posibilidad de la existencia de nihilistas activas. Antes de morir, apuntó la siguiente idea:

Una mitad de la humanidad es débil, típicamente enferma, variable, inconstante; la mujer tiene necesidad de la fuerza para agarrarse a ella, para inventar una religión de la debilidad que venere como a cosas divinas a los seres débiles, el amar, el ser humildes; o, mejor: la mujer hace débiles a los fuertes, y reina, claro está, cuando consigue dominarles. La mujer se ha aliado siempre con los decadentes, con los sacerdotes, contra los "poderosos", contra los "fuertes", contra los 'hombres' (VP, pp. 468-469) ${ }^{18}$.

Es probable que haya una relación entre la misoginia de Nietzsche y su falta de contacto con el sexo femenino. La única vez que Nietzsche tuvo contacto con una mujer, resultado de una broma, contrajo una enfermedad sexual, la misma que, probablemente, lo condujo a su enfermedad mental, condición de la que sufría al escribir su Voluntad de poderío.

Se pueden resumir, entonces, las características principales del nihilismo pasivo de la siguiente manera: 1) la moral cristiana tradicional; 2) una existencia sin fin; 3) el anhelo de beatitud; 4) la decadencia del espíritu; 5) la pasión concebida como el mal; 6) la aflicción de una enfermedad que consiste en la negación de la fuerza vital; y por tanto, 7) una debilidad general asociada con la mujer.

Reflejando el pensamiento de Nietzsche, Concha lleva en su alma lo que el filósofo teutónico designó como "un aborto de cadáver". Por eso, está "muy enferma", su constitución es "pálida" (p. 14), su boca se ve como "una rosa descolorida" (p. 15), y ella misma se muestra completamente "demacrada por la enfermedad" (p. 22). Su piel es "blanca y pálida como la luna" (p. 23), como si fuera "un fantasma"' (p. 24). Tiene "ojos de enferma" (p. 45) por encima de su "sonrisa de enferma" (p. 60). En fin, la enfermedad de Concha es una de las constantes más sobresalientes de la obra. Es verdad que se arregla, es decir, que

18 " Die Eine Hälfte der Menschheit ist schwach, typisch-krank, wechselnd, unbeständig, - das Weib braucht die Stärke, um sich an sie zu klammern, und eine Religion der Schwäche, welche es als göttlich verherrlicht, schwach zu sein, zu lieben, demüthig zu sein-: oder besser, es macht die Starken schwach, -es herrscht, wenn es gelingt, die Starken zu überwältigen. Das Weib hat immer mit den Typen der décadence, den Priestern, zusammen conspirirt [sic] gegen die «Mächtigen» die "Starken», die Männer-" (GW, t. 19, p. 261). 
se peina, se perfuma y se viste, pero no se alimenta correctamente. Debido a su interés en la Voluntad de Dios, no se preocupa por la salud física. Entonces, su cuerpo está convirtiéndose "en un aborto de cadáver". Esta coincidencia entre Nietzsche y ValleInclán se presenta en el uso paralelo del adjetivo "pálido". Se verifica también en el empleo del sustantivo "enfermedad" en Valle-Inclán que concuerda con el adjetivo "enfermizo" en Nietzsche. Esta concomitancia sugiere que el estado moribundo de la existencia física de Concha resulta del nihilismo pasivo.

La enfermedad física de que sufre se extiende al nivel mental también. Se ha dicho que la moral tradicional inculca en el creyente un sentimiento de culpa y de miedo. La beatitud de Concha es representada por "su alma devota"' (p. 75). Siendo beata, ha renunciado a la Voluntad y no le queda más remedio que condolerse. El narrador (el marqués) explica que "lloraba de amor, y de miedo a las penas eternas" (p. 8). Su "miedo a las penas eternas" arranca de lo que Nietzsche ha denominado el "sentimiento de miedo y temor ante sí". Este miedo se impone frente a lo que Nietzsche ha llamado "la gran máquina de castigar" que funciona "más allá de la vida". Concha es víctima de la ideología cristiana que la aparta de su propia Voluntad frente al terror de la Voluntad divina. Junto a su veneración de amor, Concha sufre el peso de la culpa por haber seguido su instinto y su pasión hacia su primo, el marqués. La pasión, para ella, no tiene nada que ver con la naturaleza, con el instinto, sino que se asocia con la Voluntad personal. Es una pasión que, "apartada" de la Voluntad de Dios, se percibe como el Mal. Al aceptar la moral cristiana, Concha padece por su conducta. El marqués explica que " "era muy piadosa la pobre Concha, y sufría porque nuestros amores se le figuraban un pecado mortal" (p. 8). Para el nihilismo pasivo, el pecado es resultado de la Voluntad humana. El hecho de cometer un pecado mortal significa ir al infierno, el terror a “ "un más allá de la vida”: “ "morir en pecado mortal. . . QQué horror!" (p. 23). El marqués, libre de la moral cristiana, analiza la situación. Siendo nihilista activo, concibe un mundo sin pecado: " A pesar de nuestros amores, Concha no se condenaría" (p. 52). Niega el concepto cristiano del pecado: "El laberinto era el pecado en que Concha estaba perdida” (id.). Desde la perspectiva del marqués, la moral de Concha se ha convertido en un "laberinto" sin salida a no ser por el nihilismo activo. Pero ella no ve esa realidad y se horroriza. Sabe que va a morir y le aterroriza el juicio divino: "mañana quiero confesarme . . ¡Temo tanto ofender a Dios!" 
(p. 78). El sentimiento de culpa que sufre arranca del "temor ante sí mism[a]". Este sentimiento de culpa aumenta frente a "la gran máquina de castigar” de Nietzsche: “iBien castigada estoy!... ¡Bien castigada estoy!'” (p. 66).

Concha, al subordinarse a la moral cristiana, pone la Voluntad de Dios por encima de la suya. Ama pero no piensa en este amor en sí; se preocupa del amor no como fin sino como medio para llegar al pecado. Este yerro frente a Dios se cumple por ser tanto prematrimonial como incestuoso. De esta suerte tiene una existencia bastante inquieta, sufre de esta "moral" y se pone cada vez más enferma. Esta moralidad la aparta de su verdadera naturaleza espiritual.

Lo opuesto al nihilismo pasivo es el activo. Ferrater Mora explica que, en el nivel más básico, la función del nihilismo activo procura "destruir el sistema de valores de aquel nihilismo pasivo tradicional"' (FM, t. 2, p. 557). Es la rectificación de la pasividad enfermiza del ente humano. Se encarna en los nihilistas activos porque son los que "quieren la victoria, quieren adversarios vencidos, quieren extender su poderío sobre territorios más extensos que los que ocupan en la actualidad" (VP, p. 385) ${ }^{19}$.

Esta lucha del nihilismo activo frente al pasivo no se encuentra sin resistencia: "la moral era el gran antídoto contra el nihilismo práctico y teórico" (VP, p. 33) ${ }^{20}$. Para el nihilista pasivo, si la moral simboliza el Bien, la amoralidad representa el Mal. Esta relación entre el Bien y el $\mathrm{Mal}$ se ve solamente dentro del contexto judeocristiano. El nihilista activo niega todo ese trasfondo: " $\mathrm{Si}$ consideramos empíricamente cada uno de los casos en los cuales un hombre sobrepasa la medida humana, veremos que cualquier grado superior de poderío presupone la libertad frente a lo bueno y lo malo y también ante lo verdadero y lo falso"' $(V P, \text { p. } 157)^{21}$. El nihilista activo no solamente destruye la dualidad cristiana entre el Bien y el Mal sino también la oposición entre lo bello y lo feo. Negado todo concepto dualista, el nihilista activo es capaz de ir

19 "Sieg, überwundene Gegner, Ueberströmen des Machtgefühls über weitere Bereiche als bisher" (GW, t. 19, p. 150).

20 " Moral war das grosse Gegenmittel gegen den praktischen und theoretischen Nihilismus" (GW, t. 18, p. 12).

21 "Gehen wir von der Erfahrung aus, von jedem Falle, wo ein Mensch sich bedeutend über das Maass des Menschlichen erhoben hat, so sehen wir, dass jeder hohe Grad von Macht Freiheit von Gut und Böse ebenso wie von "Wahr" und "Falsch" in sich schliesst..." (GW, t. 18, p. 178). 
más allá de "la ingenuidad de nuestros ideales"' $(V P, \text { p. } 46)^{22}$. Renunciados los ideales humanos tradicionales, se puede ver que el mundo en sí tiene más valor de lo que se había pensado en el pasado ( $V P$, pp. 45-46; $G W$, t. 18, p. 28).

El nihilismo activo implica otro sistema de valores. Glorifica la Voluntad ilimitada del ente humano, ya que refuta la moral, el Bien, el Mal, lo bello y lo feo. Esta Voluntad nihilista activa busca "la victoria", siente orgullo a causa de los "adversarios vencidos" e intenta "extender su poderío". Para el nihilista activo, el culto a Dios es cosa histórica. Su culto tiene que ver con la Voluntad, la pasión, la voluptuosidad y la aventura. El reto es supremo. Sin nexos exteriores, el nihilismo activo se convierte en una especie de espiritualismo interior. De ahí que el nihilista activo se caracterice por rasgos opuestos a los del "ser-rebaño": 1) la omnipotente Voluntad humana; 2) una mentalidad aristocrática activa; 3) la negación de la moral cristiana; 4) la deificación de la pasión, de la voluptuosidad y de la aventura; 5) la animalidad, y 6) para buscar la totalidad del ser humano, un fuerte autoespiritualismo.

El nihilismo activo del marqués se convierte en el adversario del nihilismo pasivo de Concha. Al comenzar la novela, vuelve el marqués al palacio, y con él, regresa el nihilismo activo. Así puede levantarse por encima de la moral cristiana para resucitar otro tipo de existencia. Dentro de este contexto no hay, como sugiere Zamora Vicente, una "complacencia en el Mal"'23. El marqués, exponente del nihilismo activo, goza de la nietzscheana " libertad frente a lo bueno y lo malo". Esto no quiere decir que Xavier, el marqués, no se represente con elementos cristianos. Pero ya se ven otras influencias no cristianas que él usa para forjar su destino. Vive más allá de la dicotomía del Bien y del Mal, y por ello, se le distingue como cristiano amoral. Gonzalo Sobejano llega a creer que el marqués "alía a un catolicismo tradicionalista respetuoso y litúrgico la más paladina indiferencia moral" (GS, p. 216). Sin embargo, su poderosa Voluntad no tiene que ver con el libre albedrío porque no escoge entre el Bien y el Mal cristianos sino que opta por el desarrollo personal, sin pensar en ninguna moral. Lo que elige puede encajarse en el concepto del Bien

22 "die Naivetät [sic] unserer Ideale" (GW, t. 18, p. 28).

${ }^{23}$ Alonso Zamora Vicente, Las sonatas de Valle Inclän, Gredos, Madrid, 1955, p. 53. En adelante, las referencias a este libro irán abreviadas en $Z V_{1}$ con el número de la página entre paréntesis. 
cristiano, el Mal, o en otra doctrina no cristiana. Por ejemplo, cuando la hija del molinero le ofrece las "yerbas mojadas" para Concha (p. 12), las acepta aunque no armonizan con el concepto del Bien cristiano. El marqués no quiere que Concha muera y, por esto, aceptará cualquier ayuda, ya sea cristiana o no. Así las pone debajo de las almohadas de ella (p. 26).

Muchos han notado el aspecto "satánico" del marqués ${ }^{24}$. Sin embargo, como indica Manuel Bermejo Marcos, es un "satanismo más sugerido que conformado" 25 . Se sugiere el satanismo sólo dentro del contexto Bien-Mal. Dentro del nihilismo, no existe. Esta mal llamada característica "satánica" no es nada más que el marqués viviendo según su propia Voluntad. Cuando Concha le pregunta por su ausencia, él responde que "no volví porque esperaba que tú me llamases. ¡Ah, el Demonio del orgullo!' (p. 22). Esta expresión, que evoca al orgullo como algo demoníaco, arranca del hecho que un buen cristiano deberá ser humilde ante Dios y ante su prójimo. Al no ser humilde, el cristiano tradicional se aleja del Bien. El marqués, siendo nihilista activo, no puede ser humilde, sino soberbio, orgulloso y ajeno, por tanto, a la moral cristiana. Cuando tiene que escoger entre el contexto cristiano y otro, siempre selecciona el que le conviene: "yo he preferido siempre ser el Marqués de Bradomín, a ser ese divino Marqués de Sade" (p. 38). Tampoco es tan perverso como le acusan: "y bien sabe Dios que la perversidad, esa rosa sangrienta, es una flor que nunca se abrió en mis amores" (id.). Se trata de una cuestión semántica, nada más. Para él, la pasión libre no es perversa, sino natural. Así se podría concluir que el marqués no es perverso ni satánico, sino más bien un nihilista activo.

Hay un curioso paralelo en la Sonata de otoño entre el marqués y Jesucristo. No es la primera vez que se afirma un vínculo entre Jesucristo y las obras de Valle-Inclán. Alan E. Smith subraya "la coincidencia de motivos" entre Luces de Bohemia y los Evangelios $(A S$, p. 57). Otra vez Nietzsche aporta el punto de partida para

${ }^{24}$ Hay varios estudios sobre la tendencia a caracterizar al marqués como satánico. Véase Robert Marrast, "Religiosidad y satanismo, sadismo y masoquismo en la Sonata de Otoño", CuH, 1966, núms. 199/200, esp. 489-490; y GERARD Cox Flynn, "The adversary: Bradomín", HR, 29 (1961), 120-130; también importante es el capítulo de Zamora Vicente, "Religiosidad, satanismo" ( $Z V$, pp. 46-61).

${ }^{25}$ Manuel Bermejo Marcos, Valle-Inclán: introducción a su obra, Anaya, Salamanca, 1971, p. 66. Todas las referencias a este estudio irán abreviadas en $B M$ con el número de la página entre paréntesis. 
la relación. Si el catolicismo se define como nihilismo pasivo por seguir las ovejas la moral sin discusión, no hay nada más alejado de la vida de Cristo que el cristianismo. Jesucristo destacó su individualismo al enfrentarse con el Imperio romano y el judaísmo ortodoxo. Los conceptos de paz y amor eran muy contrarios a la realidad romana y así Jesucristo era nihilista activo por antonomasia. La dicotomía entre Jesucristo y el cristianismo se resuelve al distinguir el nihilismo activo de Jesucristo del pasivo procedente del posterior cristianismo tradicional. Este mismo nihilismo activo de Cristo vale como la única fuerza de la novela que puede amenazar al del marqués. Así, el marqués no tiene miedo sino a dos cosas: la poderosa figura de Jesús y la ausencia de la mujer a quien rinde culto. Jesucristo es el único ser evocado en la novela tan poderoso como él.

Tres veces se menciona la figura de Cristo. La primera vez, en el pasillo del palacio, solamente se hace referencia a la existencia de su imagen: "En un testero arrojaba cercr mortecino de luz, la mariposa de aceite que alumbraba los pies lívidos y atarazados de Jesús Nazareno" (p. 24). La segunda vez, el marqués se distingue como el mismo Jesucristo en la escena en que muere Concha. Le dice a ella: “- ¡Azótame, Concha! ¡Azótame como a un divino Nazareno![...] ¡Azótame hasta morir!’” (p. 78).

Cabe decir que Cristo, al ser nihilista activo, pareció asociarse con el Mal para sus contemporáneos. Por esto lo crucificaron. De la misma manera, cuando el marqués se porta como nihilista activo, también es asociado con el Mal. Para su prima, este "mal" parece encarnar el diablo. Concha grita: "-Me das miedo cuando dices esas impiedades. . . Sí, miedo, porque no eres tú quien habla: es Satanás... Hasta tu voz parece otra [...] ¡Es Satanás!" (p. 78). El miedo de tal "blasfemia'” es el golpe final para ella, $\mathrm{y}$ al fin fallece. Pero no es que Xavier esté poseído, sino que Jesucristo es el más noble, el más elevado de todos los hombres de la historia, más grande que Roldán y Fernando el Católico, los dos mencionados en la novela. A diferencia del cristianismo posterior, Jesucristo, el proto-cristiano, es un nihilista tan poderoso que realmente puede infundirle miedo al marqués. La última mención de Jesucristo viene cuando el marqués lleva el cadáver de Concha a su habitación: "Allá, en el fondo de la antesala, brillaba la lámpara del Nazareno, y tuve miedo de cruzar ante la imagen desmelenada y lívida. ¡Tuve miedo de aquella mirada muerta!'” (p. 82). No percibe a Jesús como un ser resucitado. Lo percibe como si tuviera una "mirada muerta". Como Jesús puede 
morir, es hombre, y por lo que había hecho en su vida, se acerca al ideal del superhombre. Es este ideal, simbolizado en la persona de Jesucristo, el que, a la vez, atrae y aterroriza al marqués.

Teme a Cristo por su magnitud, su nobleza de espíritu. El culto de Xavier no es ni a Satanás ni a Dios. Va dirigido hacia la mujer y el placer. Su adoración hacia la mujer es tan fuerte que puede calificarse de "hembramanía". Desprovisto de toda modestia y sumisión, dispuesto a seguir su Voluntad, puede "pasar por soberbio entre algunas mujeres" (p. 38), como el típico don Juan de Tirso o el de Zorrilla. Pero a diferencia de éstos, Bradomín se encuentra libre de la moral cristiana como don Félix, calavera donjuanesca de Espronceda. Su culto a la mujer se caracteriza por la deificación de la pasión, la voluptuosidad y la aventura. La apoteosis de estos conceptos lo emparenta otra vez con el nihilismo activo.

$\mathrm{Su}$ Voluntad es tal que todo se subordina a su culto por la mujer. Tal actitud se intuye desde muy temprano en la novela cuando le pone las ropas a Concha. Esta escena patentiza la sensualidad que impulsa el culto del marqués:

Después de las medias de seda negra, le puse las ligas, también de seda, dos lazos blancos con broches de oro. Yo la vestía con el cuidado religioso y amante que visten las señoras devotas a las imágenes de que son camaristas. Cuando mis manos trémulas anudaron bajo su barbeta delicada, redonda y pálida, los cordones de aquella túnica blanca que parecía un hábito monacal [...] (p. 17).

Las connotaciones sagradas son obvias. Tiene "broches de oro", como los reyes-sacerdotes aztecas en tiempos posclásicos mexicanos. Él tiene "manos trémulas" al atender al objeto de su culto vestido en "hábito monacal". El adorante se pone de rodillas frente a la diosa y la venera con "cuidado religioso".

A través de su adoración de la mujer, se ven dos fenómenos importantes: la deificación de la pasión y de la voluptuosidad. Ya se ha visto el lenguaje que usa al vestir a su prima. Con imágenes que traen a la memoria la mística de la tradición judeocristiana, se presentan escenas en las que el alma tiembla al unirse con la Amada: "Amorosa y complaciente, echó sobre mí el velo oloroso de su cabellera. Yo respiré con la faz sumergida como en una fuente santa, y mi alma se llenó de delicia y de recuerdos florecidos. El corazón de Concha latía con violencia, y mis manos trémulas desabrocharon su túnica, y mis labios besaron sobre la carne, ungi- 
dos de amor como de un bálsamo...' (p. 23). El alma llena de delicia y de "recuerdos florecidos" parece un lecho sagrado que se ve próximo a la “fuente santa”. Este lecho de amor carnal, a través de las imágenes metafóricas de la unión mística con la Esposa, representa la deificación de la pasión. En otro lugar, repleto también con la idea de un éxtasis espiritual del alma, se presenta el culto a la voluptuosidad: "Con voluptuosidad dolorosa y no gustada hasta entonces, mi alma se embriagó en aquel perfume de flor enferma que mis dedos deshojaban consagrados e impíos" (p. 47). La apoteosis de la pasión y de la voluptuosidad se verifica en el tratamiento de las cartas de amor como textos sagrados. Pero no sagrados como la Biblia, por ejemplo, sino como un ejemplar de la única edición de un libro de poesía: "Yo me he resistido siempre a quemar las cartas de amores. Las he amado como aman los poetas sus versos', (p. 39). Aquí se pone de manifiesto el culto modernista al arte, basado en el concepto nietzscheano del artista ${ }^{26}$. La creación personal se coloca por encima de todo, aunque se trate de cartas amorosas llenas de sentimientos superiores. Esta creación personal es un reflejo de la deificación del sentimiento, la voluptuosidad y la pasión.

La pasión sin freno moral del marqués se relaciona con su Voluntad de seguir sus instintos animales ${ }^{27}$. Esta tendencia es la que Nietzsche llamó "magnífica animalidad". Siguiendo las normas de la animalidad humana, el individuo puede crearse sin preocuparse por las reglas morales del cristianismo. Ya se ha mencionado la característica donjuanesca del marqués, fruto de su culto a la mujer y a la aventura. Al morir Concha, hace el amor con su otra prima, Isabel. Pero entonces no habla de su Voluntad sino de su flaqueza (p. 81). La explicación se encuentra otra vez en Nietzsche. El amor sexual "quiere sojuzgar, poseer, y aparece como una entrega de sí mismo" (VP, p. 417)28. Para Nietzsche, "el amar" pertenece a las mujeres, no a los hombres. Corresponde a "una religión de la debilidad". Pero la flaqueza es sólo una apariencia aquí porque el marqués cumple con su pujante Voluntad.

${ }^{26}$ Una buena exposición sobre el concepto del artista nietzscheano se encuentra en Howard Giskin, "El hombre selecto como artista en Ortega y Gasset y en Nietzsche", NRFH, 34 (1985-86), 181-193.

27 Bermejo Marcos estudia este tema desde otra perspectiva en "Animalización y otros recursos «esperpentizantes»", en su Valle-Inclan: introducción a su obra (BM, pp. 74-84).

28 "sie will die Ueberwältigung, das In-Besitz-nehmen, und sie erscheint ais Sich-hingeben" (GW, t. 19, p. 192). 
De nuevo hay una cierta influencia cristiana que, como se ha mencionado, sigue actuando en el marqués. Esta influencia toma la forma de una presupuesta flaqueza. Sin embargo, el influjo nietzscheano es mucho más poderoso que el católico. Explícitamente, Nietzsche escribe que "En el fondo, es solamente el amor al propio instrumento, al propio caballo, la convicción de que una cosa nos pertenece y que nos podemos servir de ella" (VP, p. 417) ${ }^{29}$. De esta forma, la mujer nietzscheana "pertenece" al hombre "nietzscheano", y él no hace más que "servir[se] de ella". En vez de amarla por su espíritu o su intelecto, la adora como objeto. Este proceso de cosificación abre un abismo entre los dos sexos tal como la novela los presenta. El hombre no está con la mujer. Está por encima de ella físicamente y para compensarlo, la eleva hasta que se convierte en objeto de veneración. Pero la apoteosis de la pasión no repara la brecha que impide que la relación vaya más allá de lo físico.

Después de morir Concha, Xavier se encuentra en un vacío parecido al del Occidente al saber que la Verdad no tiene nada que ver con el ideal cristiano (VP, pp. 34-35; $G W$, t. 18, p. 13). Llora la pérdida de su diosa profusamente:

¡La pobre Concha había muerto! ¡Había muerto aquella flor de ensueño a quien todas mis palabras le parecían bellas! ¡Aquella flor de ensueño a quien todos mis gestos le parecían soberanos! . . ¿Volvería a encontrar otra pálida princesa, de tristes ojos encantados, que me admirase siempre magnífico? Ante esta duda lloré. ¡Lloré como un Dios antiguo al extinguirse su culto! (p. 86).

De esta manera, termina la novela. Muerta la mujer, el objeto de su culto, volverá a ser nihilista aristocrático y así, encontrará a otra. Pero ella tendrá que ser nihilista pasiva, simbolizada en el deseo del marqués de encontrar "otra pálida princesa". El vocablo clave aquí es "pálida", que revela que el objeto del deseo debe ser una nihilista pasiva. Así se puede cumplir completamente con los deseos de su Voluntad. En fin, se advierte cómo el espiritualismo del marqués no tiene nada que ver con Dios sino que se deriva de la contemplación de un objeto externo: el culto a la mujer. La apoteosis de la pasión del nihilismo activo es tan fuerte que, ante Concha, tiemblan su alma y sus manos.

29 "Im Grunde ist es nur die Liebe zu seinem "Werkzeug", zu seinem "Pferd", - seine Ueberzeugung davon, dass ihm das und das zugehört, als Einem, der im Stande ist, es zu benutzen..." (GW, t. 19, p. 192). 
Aunque la temática de la Sonata de otoño se ha tachado de permanecer "reclusa en su alta torre de arte y de superioridad" ( $Z V$, p. 100), se verifica ahora que está empapada de la filosofía nihilista de Nietzsche. Se ha examinado cómo tanto en la Sonata de otoño como en la Voluntad de poderio el nihilismo activo es representado por el hombre mientras que se percibe a la mujer como la pasiva-piadosa. La mujer sufre del temor al pecado, la culpa y las penas eternas, mientras que el hombre se ha liberado de toda práctica cristiana tradicional, excepto la del rezo. El marqués cree en Dios, pero, como para tantos escritores modernistas ${ }^{30}$, ya no es el Dios cristiano. Para Gonzalo Sobejano, Valle-Inclán no pudo "prescindir de la idea del pecado" (GS, p. 214). Sin embargo, por lo menos en la Sonata de otoño, el marqués no se arrepiente de ser mujeriego. Su temor a Jesucristo no tiene que ver con ningún concepto del pecado sino con el temor a otro nihilista activo. Esta actitud se aprecia claramente cuando desea ser azotado como el Nazareno. Guando el marqués entra en el cuarto de Isabel, ninguno de los dos se preocupa del pecado. Isabel se inquieta de "que se aparezca Concha", mientras que el marqués se contenta tan sólo de que sea Concha - no Dios- la que "lo habrá perdonado allá en el Gielo"' (p. 81). En esta escena el único concepto cristiano (que arranca del paganismo) arraigado en el marqués es el de la mujer como tentadora.

El nihilista pasivo percibe los instintos animales de pasión, voluptuosidad y aventura como hechos impulsados por el Mal, cuando no vinculados al mismo. En cambio, el nihilista activo es impulsado por su poderosa Voluntad. Pone su Voluntad por encima de la de Dios mientras que el nihilista pasivo se deja guiar por la divina. Así Valle-Inclán no eleva el sensualismo al nivel cristiano, como se ha sugerido recientemente ${ }^{31}$. Lo que hace es negar nihilistamente lo religioso, proceso que, por su misma naturaleza, glorifica lo carnal. Lleva el sensualismo al nivel espiritual, diferenciado de las prácticas religiosas del cristianismo. En esta obra el nihilista aristocrático usa su Voluntad para conformarse a sus impulsos más apasionados y animales. Cuando el objeto de estas pasiones desaparece, él siente el vacío de haber per-

${ }^{30}$ El ejemplo más obvio es el Dios de Rubén Darío, que es una mezcla del Dios cristiano, el pitagórico, el panteísta y el dios andrógino. Véase mi artículo, "El pensamiento religioso de Rubén Darío: un estudio de Prosas profanas y Cantos de vida y esperanza", RevIb, 55 (1989), 363-375.

31 Claire J. Paolini, Valle-Inclán's Modernism. Use and abuse of religious and mystical symbolism, Albatros, Valencia, 1986, p. 100. 
dido contacto con su "valor absoluto".

Para caracterizar esta obra modernista del primer Valle-Inclán, se puede aplicar una idea de Cathy Jrade sobre el pensamiento de Rubén Darío. La Sonata de otoño se apartó de la tradición hispana que pone énfasis en el orden católico del universo ${ }^{32}$, reemplazándola con un nuevo tipo de espiritualismo modelado siguiendo a Nietzsche. Así se puede afirmar que el modernismo de esta obra no ignora las cuestiones filosóficas y sociales de su época. Esto demuestra que $s i$ se puede escribir una literatura social, que llegue a ser filosófica, dentro del estilo llamado modernista. Es menos ofensivo tratar el problema del cristianismo en un palacio mustio y lejano que en una de las realidades no modernistas creadas, por ejemplo, por Benito Pérez Galdós o Pío Baroja. Es más fácil demostrar el desequilibrio entre los dos sexos en un lugar decadente de ficción que en un artículo periodístico. Para negar el cristianismo por medio de la iniquidad sexual, habría que ir a un lugar exótico. Octavio Paz dijo una vez que "el Modernismo es una estética nihilista" "33. Es en el palacio de Brandeso donde el marqués de Bradomín niega nihilistamente la moral cristiana, para pregonar otra más vital, la de la Voluntad del ser humano.

ThOMAS ButLer WARD Loyola College, Baltimore

32 Cathy Login Jrade, Rubén Dario and the Romantic search for unity, University of Texas Press, Austin, 1983, p. 3.

33 Octavio Paz, "El caracol y la sirena", en Cuadrivio, J. Mortiz, México, 1980 , p. 23. 